\title{
Hospital visiting policies - impacts on patients, families and staff: A review of the literature to inform decision making
}

\author{
Lynda Bélanger, Sylvain Bussières, François Rainville, Martin Coulombe, Marie Desmartis
}

CHU de Québec-Université Laval, Canada

Received: October 4, 2017

DOI: $10.5430 /$ jha.v6n6p51
Accepted: November 8, 2017

Online Published: November 21, 2017

\begin{abstract}
Some healthcare organizations recommend adopting open visiting policies. These organisations are working towards the end goal of promoting the idea that patients and families can be true partners in care. An essential step in this culture shift involves openness to family presence and their engagement in the patient's care. Among other things, their recommendations are based on data from studies that assessed the impacts of different types of visiting policies on patients, families and healthcare staff. In order to inform and guide an organizational reflection on possible changes to our hospital center's visiting policies, our team undertook a systematic review that focussed on the advantages and disadvantages of open/flexible visiting policies, as perceived by patients, families and staff. Review articles and original articles were assessed and synthesized following a rigorous review process. Results of the reviewed studies suggest that flexible visiting policies lead to greater patient satisfaction with care and to positive impacts for both patients and families, and that these stakeholders have clear preferences for open/flexible policies. Nevertheless, policies including some guidelines to safeguard rest and sleep periods were deemed necessary by patients, rather than an unqualified open policy. Results also suggested that flexible visiting hours were not associated with an increased risk in hospital-acquired infections or septic complications in intensive care units (ICUs), where the majority of the reviewed studies were carried out. Authors recommended taking the specific context of care units into account when implementing new visiting policies, as needs may be different according to different health issues. Staff preferences over a model or the other were somewhat mixed. Some staff see the presence of families and visitors as an obstacle to the provision of care and a reason to fear increased workloads. In order to overcome this resistance, the importance of adequately preparing staff and supporting them throughout the policy change to ensure its success is highlighted.
\end{abstract}

Key Words: Hospital, Visiting polices, Patient experience, Organisational change, Patient and family-centered care, Caregiver presence

\section{INTRODUCTION}

Our organisation, which has been working towards adopting more patient and family centered-care practices, made patient experience its chief strategic direction for 2014-2020. Six specific goals were established under this strategic di- Several types of visiting policies are currently in effect in

\footnotetext{
*Correspondence: Lynda Bélanger; Email: Lynda.Belanger@chudequebec.ca; Address: CHU de Québec-Université Laval, 10 rue de l’Espinay, Bureau D7-724, Québec (Québec), G1L 3L5, Canada.
}

Published by Sciedu Press 
Canadian hospitals and elsewhere around the world, ranging from open policies, i.e. allowing the presence of one or several visitors at all times, to very restrictive policies that do not allow their presence for more than a few minutes per hour. On the whole, in North America, restrictive policies are still the most widespread. ${ }^{[1]}$ Historically, patient visits have been restricted with a view of maintaining order, organizing work and preventing infections, for example during outbreaks such as Severe Acute Respiratory Syndrome (SARS). ${ }^{[2,3]}$ According to this restrictive approach, several negative aspects were associated with the presence of visitors, who were perceived as sometimes disruptive, noisy, infection-spreading, requiring staff members' time and even hindering care. ${ }^{[4]}$ However, the strict rules that govern visiting hours are now increasingly questioned. According to some authors and to some organizations that promote quality improvement in healthcare services, several visiting policies currently enforced by hospitals are unduly restrictive and associated with several negative effects on patients and families. ${ }^{[5-7]}$ In addition, these restrictions may primarily be based on myths, assumptions or organizational precedents rather than evidence. ${ }^{[3,8]}$ Finally, some authors emphasize that visiting policies that are clearly set out and communicated to patients, families, and staff may curtail arbitrary decisions made by staff with respect to visiting rights and may dispel myths. ${ }^{[4]}$

In 2009, the Institute for Patient and Family-Centered Care (IPFCC) established a work group composed of healthcare organization leaders, healthcare professionals, patients and families, who were mandated to develop guidelines with a view to changing policies and practices regarding hospital visits. The Better Together campaign was subsequently launched across North America. This campaign urges hospitals to adopt visiting policies that are focused on the needs of patients and families by allowing patients to designate persons who can stay by their side 24 hours a day, seven days a week, if they so choose (These designated persons will be further referred to as caregivers in the text in order to distinguish them from other visitors including family members and friends. Also, for concision sake, the terms family or family members also include friends and any person considered as such by the patient).

It is against this backdrop that our Steering Committee is considering the possibility of revising its family presence and visiting policies, in order to offer more flexibility for caregivers. However, the Committee felt it needed more information on how patients and their families viewed visiting policies and about the impacts of open/flexible policies on patients, families and staff to get a broader view of the implications surrounding such a change. In order to guide this reflexion, we conducted a search of the literature and identi- fied a number of reviews which looked at different aspects of patient, family and staff experience in relation with visiting policies. We thus synthesized evidences from the published reviews and practice guidelines. We were specifically interested in three aspects: (1) What are the impacts of open or flexible versus restrictive visiting policies, as perceived by patients and families? (2) What are the impacts of open or flexible visiting policies on the work of staff, as perceived by nurses and other healthcare professionals? (3) What potential risks, specifically the risk of hospital-acquired infections, do open or flexible visiting policies pose?

\section{METHODS}

\subsection{Literature search}

Indexed databases in Medline (PubMed) and Cumulative index to nursing and allied health literature (CINAHL) were searched in order to identify synthesis studies, with or without meta-analyses, as well as evidence-based practice guidelines published since 2005. Bibliographies of relevant articles were reviewed to identify other references of interest. Table 1 lays out the eligibility criteria, limits and indicators which were set out to conduct our literature seach as well as out search stategy. We conducted an additional separate search on risks of hospital-acquired infections and complications, in which we searched for original studies since the topic was only indirectly addressed in the reviews we identified.

\subsection{Selection and evaluation of the eligibility}

Selection of the studies was conducted independently by two reviewers (M.D. and S.B.) based on the inclusion criteria and limits outlined in Table 1. In case of disagreement, the opinion of a third evaluator (L.B.) was sought in order to reach a consensus.

\subsection{Assessment of the quality of the publications and data extraction}

Quality of the publications was assessed independently by two reviewers (S.B. and M.D). The methodological quality of systematic reviews and practice guidelines was assessed through R-AMSTAR ${ }^{[9]}$ and AGREE-II ${ }^{[10]}$ grids, respectively. The opinion of a third evaluator (L.B.) was requested in case of a disagreement on the quality of a paper to achieve consensus. Data extraction was done by a first reviewer (M.D.), using a grid that was specific to this project, and was validated by a second reviewer (S.B). 


\section{Results}

3.1 Perceived impacts of open visiting policies and preferences of patients, families and staff

A total of 276 different documents were identified. The document-selection diagram is outlined in Figure 1. After reviewing titles and abstracts, 25 publications were selected and assessed. Four other documents were selected from the bibliography of eligible studies. In total, 29 documents were selected to assess eligibility from their full text. Of this number, 18 documents were excluded. Eleven documents were included, seven literature reviews ${ }^{[8,11-16]}$ and four practice guidelines. ${ }^{[1,4,17,18]}$

Table 1. Eligibility criteria, limits and search terms

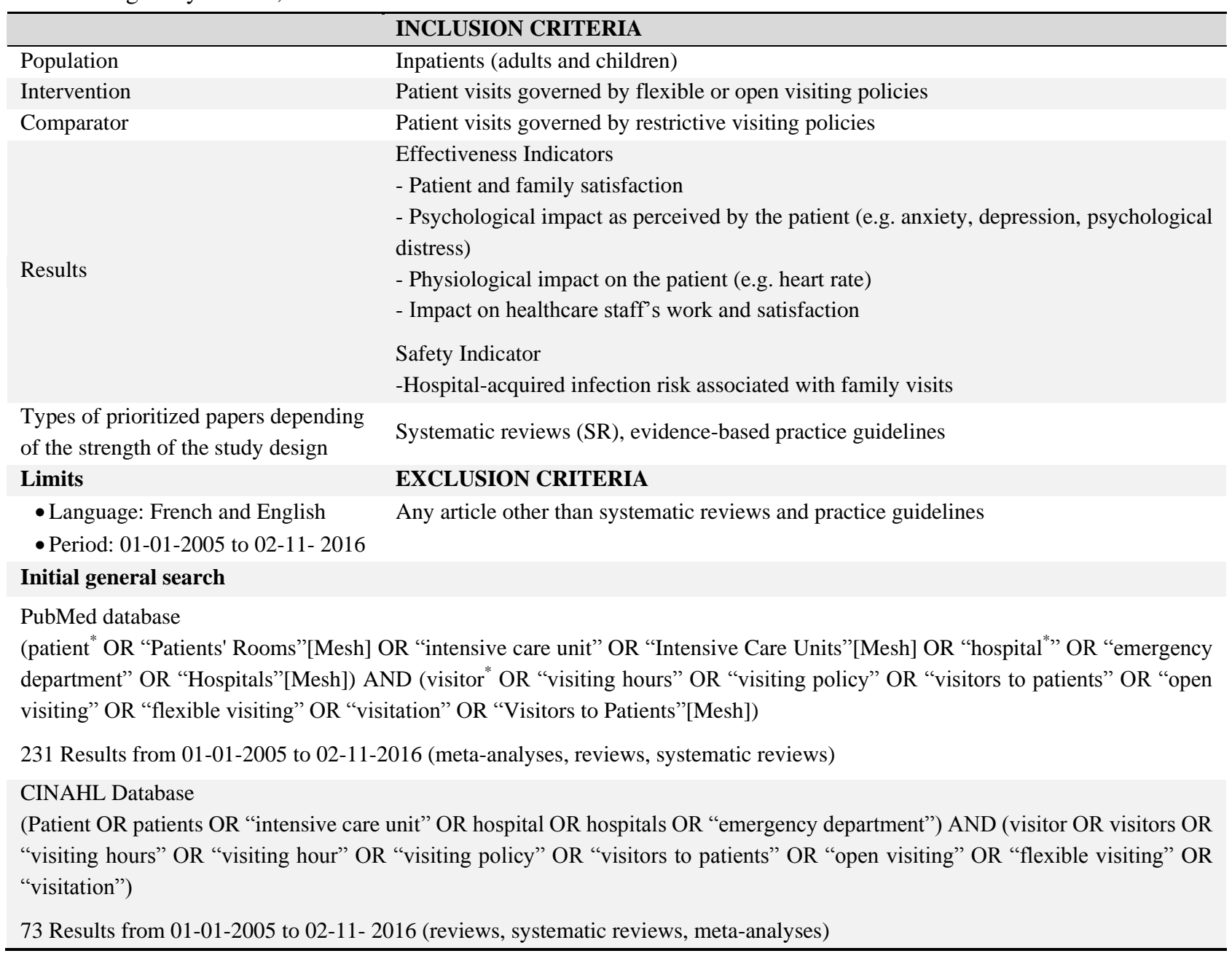

Among the seven reviews included, five were exclusively focussed on intensive care units (ICUs) ${ }^{[11,12,14-16]}$ while the other two were not confined to a specific type of unit. ${ }^{[8,13]}$ While most of the reviews had the overarching goal of assessing and synthesizing evidence on the perceived impacts on patients, visitors and staff of open or flexible visiting policies, they varied in types of studies they included, indicators and methodologies they used to assess impacts. The quality of their methodologies. Among the seven papers included in our study, we found that only three were of good quality; ${ }^{[8,12,16]}$ the others were of low-to-medium quality. ${ }^{[11,13-15]}$ Main limitations of the later were the poor research methodology descriptions, as well as poor descriptions and poor critical Published by Sciedu Press assessment of the primary studies they included. A brief description of the reviews we included in our synthesis and a summary of their results are presented in Table 2. Four practice guidelines documents or position statements from renowned healthcare organizations were also identified (see Table 3). Three guidelines documents are from professional associations in intensive care, the American Association of Critical-Care Nurses (AACN), ${ }^{[17]}$ the American College of Critical Care Medicine (ACCM) ${ }^{[18]}$ and the British Association of Critical Care Nurses (BACCN),${ }^{[4]}$ and the fourth is a position statement from the Institute for Patient-and Family-Centered Care and is aimed at all types of care units (IPFCC). ${ }^{[1]}$ 


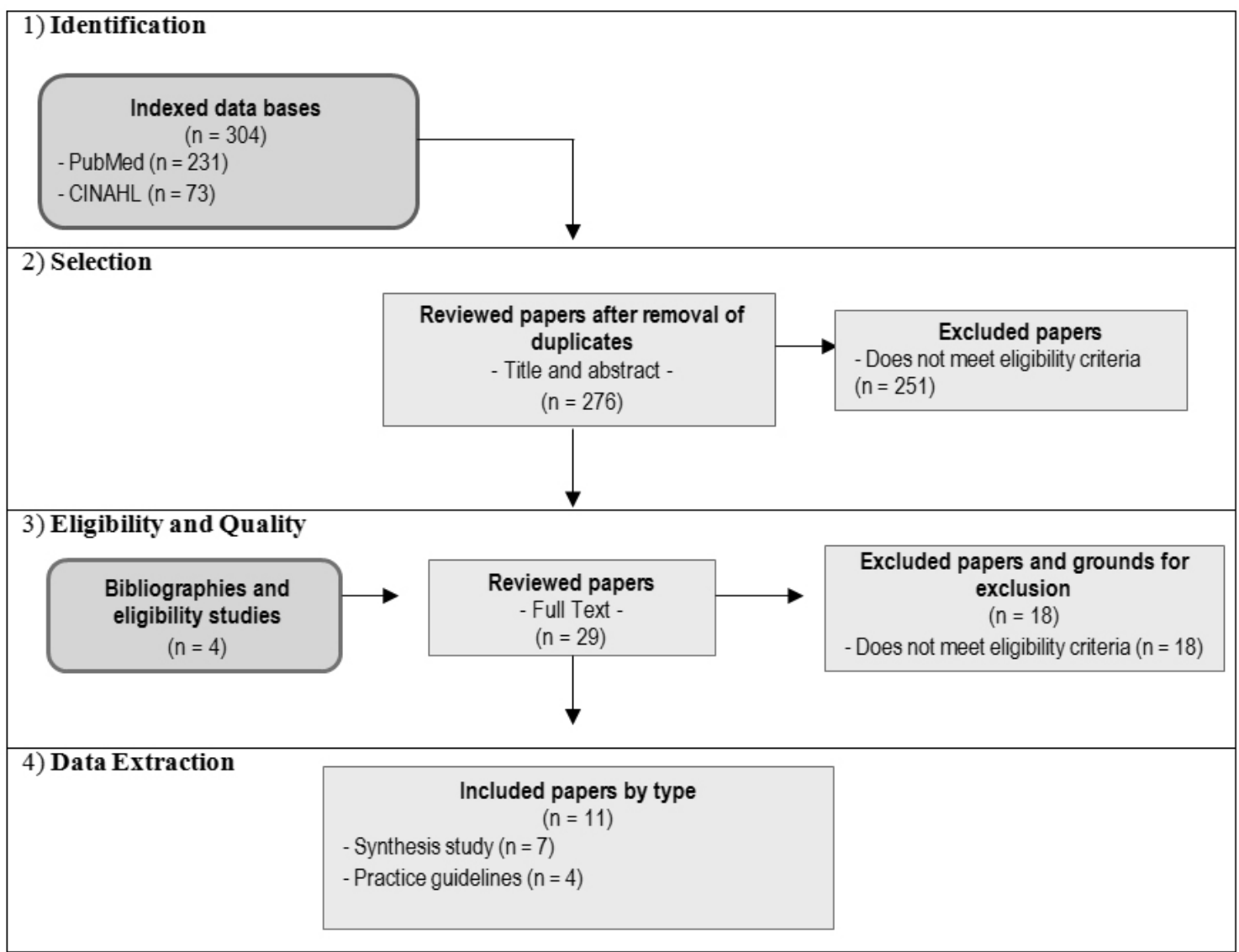

Figure 1. Document-selection diagram for the literature search on the impacts of visiting policies on patients, families and healthcare staff

Conclusions from four reviews were that flexible or open visiting hours in ICUs are linked to increased patient satisfaction, decreased anxiety and improved emotional well-being (e.g., decreased scores on depression scales)..$^{[8,11,12,15]}$ Results from one of them also suggested decreased cardiovascular complications. ${ }^{[8]}$ Increased family presence also seemed to improve communication between patients, families and care staff since these "visitors" are important sources of information on medical history and needs of the patient. ${ }^{[11,12,15]}$ For families, the benefits associated with open or flexible visiting policies included a better understanding of the patient's condition, decreased levels of anxiety and depression, as well as greater ability to participate in the patient's care and coordination of services. ${ }^{[15]}$ Benefits for nursing staff mainly included access to useful information regarding the patient, which allowed for the provision of more individualized, holistic care. ${ }^{[15]}$

Regarding preferences and needs, conclusions were that patients and families preferred more flexible visiting policies rather than restrictive ones in intensive care, especially as regards to caregivers. ${ }^{[11]}$ Nonetheless, it is important to underscore that patients did not perceive all visits as useful.
They sometimes perceived visitors as intrusive and noisy, disturbing their sleep and even causing an increase in their pain levels. Results from the Ciufo et al. ${ }^{[12]}$ review also suggest that a flexible visiting policy, which includes guidelines on how it can be adapted to various situations, would better meet the needs of patients, families and staff than an unqualified, open policy. Results from the Smith et al. review ${ }^{[8]}$ also show that in adult general care units and maternity wards, patients appear to benefit more from visiting policies that include quiet periods to promote rest (without visits) than unrestricted access to patients. In addition, the importance of respecting the patient's right to decide whether he/she wants visits from his/her family, specifically which people and to what extent they are free to visit, are important elements highlighted in most of these reviews. Authors also highlight the usefulness of "visiting contracts or plans" outlining the patient's preferences regarding people who can visit, the number of persons at any given time and the duration of the visits. They also highlight that this plan should be determined by the patient or his/her representative, should he or she not be in a position to do so, and be established in collaboration with the identified caregivers and nurses. 
Table 2. Description of synthesis studies on the impacts of visiting hours on patient and family experiences

\begin{tabular}{|c|c|c|c|c|c|c|}
\hline $\begin{array}{l}\text { Author (year) } \\
\text { [ref] }\end{array}$ & Objectives & $\begin{array}{l}\text { Type of } \\
\text { studies }\end{array}$ & $\begin{array}{l}\text { \# And types of } \\
\text { studies reviewed } \\
\text { (years) }\end{array}$ & $\begin{array}{l}\text { Clinical } \\
\text { environments }\end{array}$ & Main outcomes & Quality \\
\hline $\begin{array}{l}\text { Cappellini } \\
\text { et al. } 2014^{[11]}\end{array}$ & $\begin{array}{l}\text { Describe the current state of } \\
\text { visiting policies in ICUs at } \\
\text { the international level; study } \\
\text { the impact of open visiting } \\
\text { policies on patient, visitor } \\
\text { and staff perceptions, as } \\
\text { well as the impact on patient } \\
\text { health }\end{array}$ & $\begin{array}{l}\text { Systematic } \\
\text { Review }\end{array}$ & $\begin{array}{l}29 \text { studies, } \\
\text { primarily } \\
\text { descriptive } \\
\text { (2001 to 2012) }\end{array}$ & Intensive Care & $\begin{array}{l}\text { Great variability of visiting policies in ICUs across the country, } \\
\text { including the number of visitors allowed and rules regarding child } \\
\text { visits. } \\
\text { Patients in intensive care and their families prefer non-restrictive } \\
\text { visiting policies. Patients feel that family members provide } \\
\text { emotional support and can help them better understand the } \\
\text { information given by healthcare staff. Families are an important } \\
\text { source of information on the medical history and needs of the } \\
\text { patient. They are also more satisfied when visiting policies are } \\
\text { more open. } \\
\text { One study reported that open visiting policies had a positive impact } \\
\text { on patient depression indicators and cardiovascular complications. } \\
\text { The beneficial effects of open visiting policies are also perceived } \\
\text { by healthcare staff. However, physicians are more inclined to } \\
\text { expand visiting hours than nurses, who have more conflicting } \\
\text { views on the matter. Among the concerns raised regarding an } \\
\text { increased presence of visitors, we note the worry that visitors may } \\
\text { potentially impede the administration of care and increase the } \\
\text { burden of work. } \\
\text { Studies also looked at the risk of infection associated with a greater } \\
\text { openness to visitors in ICUs (see Table 4). }\end{array}$ & Average \\
\hline $\begin{array}{l}\text { Ciufo et al. } \\
2011^{[12]}\end{array}$ & $\begin{array}{l}\text { To evaluate and synthesize } \\
\text { the best available data on } \\
\text { visiting policies in ICUs and } \\
\text { explain their connection } \\
\text { with the key concepts of } \\
\text { patient and family centred } \\
\text { care }\end{array}$ & $\begin{array}{l}\text { Systematic } \\
\text { Review }\end{array}$ & $\begin{array}{l}\text { 13 Studies: } 7 \\
\text { quantitative } \\
\text { (questionnaires) } \\
\text { and } 6 \text { qualitative } \\
\text { (1993 to 2009) }\end{array}$ & $\begin{array}{l}\text { Adults in } \\
\text { intensive care }\end{array}$ & $\begin{array}{l}\text { Ideal visiting policies do not exist; visiting policies should be seen } \\
\text { as guidelines rather than as a set of rules to be complied with. } \\
\text { Flexible visiting policies, which can be adapted to different } \\
\text { situations, better meet the needs of patients, families and nurses. } \\
\text { Overall, patients need reassurance and support and visitors need to } \\
\text { be close to their loved ones. Although nurses perceive family visits } \\
\text { as beneficial for patients, most of them also see open or flexible } \\
\text { visiting hours as a potential obstacle to care and something that } \\
\text { could increase their workload. Therefore, some nurses prefer more } \\
\text { restrictive visiting hours. Hospital leadership should take nursing } \\
\text { staff attitudes and beliefs into account before considering a change } \\
\text { in visiting policies. } \\
\text { Discussions around visits are an opportunity for patients, families } \\
\text { and nurses to communicate openly and collaboratively by } \\
\text { establishing a visiting plan that meets everyone's needs. } \\
\text { It is important to prepare families before they enter an ICU }\end{array}$ & Good \\
\hline $\begin{array}{l}\text { Davidson et al. } \\
2014^{[13]}\end{array}$ & $\begin{array}{l}\text { Determine if concerns often } \\
\text { raised with regard to family } \\
\text { presence at the patient's } \\
\text { bedside (in particular the } \\
\text { risk of infection and a } \\
\text { potential interference with } \\
\text { clinical care) are based on } \\
\text { evidence }\end{array}$ & $\begin{array}{l}\text { Systematic } \\
\text { review and } \\
\text { case study }\end{array}$ & NR (various types) & General & $\begin{array}{l}\text { Unfounded concerns (no evidence in studies reviewed): } \\
\text { Open visiting policies increase the risk of infection. } \\
\text { Family presence during the administration of care increases the } \\
\text { risk of infection. } \\
\text { Family presence increases the risk of infection in burn patients. } \\
\text { Family presence increases the risk of infection in neonatal ICUs. } \\
\text { Family presence during patient rounding slows down the work of } \\
\text { healthcare professionals or causes a decrease in the quality of } \\
\text { patient education. } \\
\text { Family presence at night is detrimental to the physiological } \\
\text { well-being of patients. } \\
\text { Largely unfounded concerns: } \\
\text { Family presence during patient rounding increases legal risks. } \\
\text { Risks related to confidentiality must be considered, but the benefits } \\
\text { of communicating information to patients and families during } \\
\text { rounds outweigh these risks. } \\
\text { Families should be encouraged to go home to rest. } \\
\text { The decision to go home to rest or not should be at the discretion of } \\
\text { the family and should not be imposed by healthcare staff. If } \\
\text { families feel that their presence is more important than rest, it may } \\
\text { be harmful to send them home. } \\
\text { Concerns partially based on evidence: } \\
\text { Family presence during patient rounding increases their level of } \\
\text { anxiety. } \\
\text { A majority of family members prefer to be present during patient } \\
\text { rounds. However, if rounds are not adapted to family presence, } \\
\text { they can cause anxiety among families and staff. }\end{array}$ & Low \\
\hline $\begin{array}{l}\text { Hanley and } \\
\text { Piazza, } 2012 \\
{[114]}\end{array}$ & $\begin{array}{l}\text { Review literature on } \\
\text { children who visit a } \\
\text { hospitalized parent in } \\
\text { intensive care and share a } \\
\text { successful implementation } \\
\text { story of child visits to ICUs }\end{array}$ & $\begin{array}{l}\text { Systematic } \\
\text { review and } \\
\text { case study }\end{array}$ & NR & $\begin{array}{l}\text { Child visits in } \\
\text { adult ICUs }\end{array}$ & $\begin{array}{l}\text { Relevant literature supports visits paid by children to a close family } \\
\text { member's bedside in intensive care. These visits can have a } \\
\text { positive impact on the children by helping them manage and } \\
\text { understand a stressful life event. } \\
\text { Nurses need to be trained to respond to the presence of children and } \\
\text { to help support them properly and prepare them for an intensive } \\
\text { care environment. } \\
\text { Authors wrote a book to support the education of children who } \\
\text { visit a loved one in intensive care that applies to different age } \\
\text { groups. This book helped improve the comfort level of staff with } \\
\text { children visiting the unit and was perceived as a useful tool for } \\
\text { patients and families. }\end{array}$ & Low \\
\hline $\begin{array}{l}\text { Kynoch et al. } \\
2016^{[16]}\end{array}$ & $\begin{array}{l}\text { Identify best practices to } \\
\text { meet the needs of families } \\
\text { who have a critically-ill } \\
\text { loved one in intensive care. } \\
\text { The needs of the families } \\
\text { were listed in five } \\
\text { categories: support, } \\
\text { reassurance, proximity, } \\
\text { information and comfort. }\end{array}$ & $\begin{array}{l}\text { Systematic } \\
\text { Review }\end{array}$ & $\begin{array}{l}\text { Three studies on } \\
\text { visiting policies: a } \\
\text { prospective } \\
\text { observational } \\
\text { study, a } \\
\text { cross-sectional } \\
\text { study and a } \\
\text { quasi-experimental } \\
\text { prospective } \\
\text { observational } \\
\text { study (1992-2014) }\end{array}$ & Intensive Care & $\begin{array}{l}\text { In two of the three studies, more flexible visiting policies increased } \\
\text { the satisfaction of families, or families and nurses, while they had } \\
\text { no impact in the third study } \\
\text { However, these three studies include several methodological } \\
\text { weaknesses. }\end{array}$ & Good \\
\hline
\end{tabular}


Table 2. (continued.)

\begin{tabular}{|c|c|c|c|c|c|c|}
\hline $\begin{array}{l}\text { Author (year) } \\
\text { [ref] }\end{array}$ & Objectives & $\begin{array}{l}\text { Type of } \\
\text { studies }\end{array}$ & $\begin{array}{l}\text { \# And types of studies } \\
\text { reviewed (years) }\end{array}$ & $\begin{array}{l}\text { Clinical } \\
\text { environments }\end{array}$ & Main outcomes & Quality \\
\hline $\begin{array}{l}\text { Smith et al. } \\
2009^{[8]}\end{array}$ & $\begin{array}{l}\text { What is the } \\
\text { physiological, } \\
\text { psychological or } \\
\text { emotional impact of } \\
\text { visiting policies on } \\
\text { adult and pediatric } \\
\text { patients, and visitors? }\end{array}$ & $\begin{array}{l}\text { Systematic } \\
\text { Review }\end{array}$ & $\begin{array}{l}15 \text { quantitative studies } \\
\text { of various types } \\
(1995-2007)\end{array}$ & $\begin{array}{l}\text { Inclusion of } \\
3,882 \\
\text { participants, } \\
\text { mostly in ICUs }\end{array}$ & $\begin{array}{l}\text { Recommendations } \\
\text { More open visiting policies in adult ICUs should be considered } \\
\text { (B Grade). Evidence suggests that an open visiting policy may } \\
\text { be beneficial for patients and families in intensive care in terms } \\
\text { of increased satisfaction and decreased anxiety. } \\
\text { Patient-led visiting policies in intensive care should be } \\
\text { considered. It may be in the form of an individualized contract } \\
\text { (specifying the patient's preferences according to him/her or } \\
\text { his representative, who can visit, the number of people, the } \\
\text { duration of visits, etc.) or of a control device (a system } \\
\text { indicating that the patient wants to rest and invite visitors to } \\
\text { leave) (B Grade). } \\
\text { Visits to neonatal ICUs should be permitted } 24 \text { hours per day } \\
\text { for parents, as well as brothers and sisters, subject to parental } \\
\text { approval. } \\
\text { In maternity and newborn care units, a hybrid visiting policy, } \\
\text { i.e. open policy for designated persons (other parent or main } \\
\text { support) and more restrictive visiting hours for other visitors } \\
\text { should be considered. } \\
\text { A separate room to meet with families should be considered in } \\
\text { maternity units to avoid disturbing the sleep of other patients } \\
\text { during the day. } \\
\text { Visiting policies should be open for general care, but quiet } \\
\text { periods should be established to allow patients to rest without } \\
\text { any visitors. }\end{array}$ & Good \\
\hline $\begin{array}{l}\text { Whitton and } \\
\text { Pittiglio, 2011 }\end{array}$ & $\begin{array}{l}\text { Generate a better } \\
\text { understanding and } \\
\text { knowledge of the } \\
\text { effects of open } \\
\text { visiting policies on } \\
\text { patients, families and } \\
\text { nurses in ICUs }\end{array}$ & $\begin{array}{l}\text { Systematic } \\
\text { Review }\end{array}$ & $\begin{array}{l}10 \text { empirical studies } \\
(2004-2011)\end{array}$ & ICU & $\begin{array}{l}\text { The overall approach in healthcare aims to engage families. It } \\
\text { has been demonstrated that open visiting policies increase } \\
\text { family satisfaction, promote happiness and relaxation in } \\
\text { patients and improve communication between staff, patients } \\
\text { and families. } \\
\text { Family visits may interfere with the work of nurses, but the } \\
\text { benefits to patients outweigh these risks. There must be } \\
\text { guidelines to ensure families are made aware of routine care } \\
\text { procedures. } \\
\text { Although patients may wish to have visitors, they may also } \\
\text { wish to restrict visits. Rules should be established in order to } \\
\text { respect patients' preferences. } \\
\text { It is important to support healthcare staff throughout the } \\
\text { visiting policy change process to ensure its success. }\end{array}$ & Low \\
\hline
\end{tabular}

Table 3. Description of original studies on infection transmission and risks pertaining to family presence in ICUs

\begin{tabular}{|c|c|c|c|}
\hline Authors, year [ref] & Type of study & Comparisons & Results and conclusions \\
\hline Adams et al., $2011^{[20]}$ & $\begin{array}{l}\text { Case study ( } 2 \text { ICUs in the } \\
\text { same hospital) }\end{array}$ & $\begin{array}{l}\text { Rate of hospital-acquired infections pre/post } \\
\text { visiting policy change: restrictive (pre), flexible } 20 \\
\text { h/day (post) }\end{array}$ & $\begin{array}{l}\text { Hospital-acquired infection rates did not increase as } \\
\text { a result of the change in visiting policies. }\end{array}$ \\
\hline Fumagalli et al., $2006^{[19]}$ & $\begin{array}{l}\text { Randomized pilot study } \\
\text { (change in visiting policies } \\
\text { every } 2 \text { months for } 2 \text { years) }\end{array}$ & $\begin{array}{l}\text { The number of septic (in terms of pneumonia, } \\
\text { urinary tract infections, } \\
\text { generalized blood-poisoning and severe septic } \\
\text { complications) and cardiovascular complications } \\
\text { in a group of patients with restrictive visiting } \\
\text { policies }(\mathrm{n}=115) \text { and a group of patients with } \\
\text { open visiting policies }(\mathrm{n}=111)\end{array}$ & $\begin{array}{l}\text { In spite of increased microbial contamination in the } \\
\text { environment, the expansion of visiting hours in } \\
\text { ICUs was not associated with an increase in the } \\
\text { number of septic complications. The number of } \\
\text { cardiovascular complications was approximately } \\
\text { two times higher in the group with restricted visits } \\
\text { versus the group with open visits. }\end{array}$ \\
\hline Malacarne et al., $2011^{[21]}$ & Observational study & $\begin{array}{l}\text { Frequency of hospital-acquired infections in an } \\
\text { ICU in } 2006 \text { (restrictive visiting } \\
\text { policy) versus } 2008 \text { (implementation of a } \\
\text { more flexible visiting policy) }\end{array}$ & $\begin{array}{l}\text { Moving from a restrictive visiting policy to a } \\
\text { more flexible visiting policy in ICUs was not } \\
\text { associated with an increase in hospital-acquired } \\
\text { infection rates. }\end{array}$ \\
\hline Peluso et al., $2015^{[22]}$ & $\begin{array}{l}\text { Retrospective observational } \\
\text { cohort study }\end{array}$ & $\begin{array}{l}\text { Presence of respiratory syncytial virus (RSV) in } \\
\text { children who were hospitalized in } \\
\text { neonatal intensive care: } 2001 \text { to } 2006 \text { (open } \\
\text { visiting policy: Group 1) versus } 2007 \text { to } 2010 \\
\text { (restrictive policy excluding visits by children } \\
\text { under the age of } 13 \text { during RSV season: Group 2) }\end{array}$ & $\begin{array}{l}\text { The exclusion of visitors under the age of } 13 \text { during } \\
\text { RSV season (between October and March) is } \\
\text { associated with a significant reduction }(6.7 \% \text { to } \\
1.7 \%, p<.0001) \text { in the number of babies infected } \\
\text { by the virus in neonatal intensive care. }\end{array}$ \\
\hline Tang et al., $2009^{[23]}$ & Longitudinal study & $\begin{array}{l}\text { Bacterial concentrations in the air pre/post family } \\
\text { visits (measures taken once per week over one } \\
\text { year) }\end{array}$ & $\begin{array}{l}\text { Family visits were not associated with an increased } \\
\text { risk of infection in ICUs: atmospheric bacterial } \\
\text { levels were no different after family visits. Mold } \\
\text { concentrations, however, were significantly higher. }\end{array}$ \\
\hline
\end{tabular}

\subsubsection{Preferences and concerns of staff}

While some studies reported that hospital staff preferred open visiting policies, other studies showed that they preferred visiting policies that were restrictive or at least included some restrictions, such as quiet periods for patients to rest. ${ }^{[8]}$ In general, physicians seemed more inclined to advocate for greater flexibility in visiting hours than nurses, who had more conflicting views on the subject. ${ }^{[1]]}$ Although many nurses perceived family presence or visits as beneficial for patients, some believed that open or flexible visiting policies may be 
an obstacle to the effectiveness of care and may lead to an increased workload. ${ }^{[12]}$ Therefore, Ciufo et al. ${ }^{[12]}$ stress that it is important for hospital leadership to take the attitudes and beliefs of healthcare personnel into account when changing visiting policies.

In addition to concerns regarding the risk of infection, Davidson et al. ${ }^{[13]}$ assessed whether other concerns, often referred to in justifying restrictive visiting policies, were based on evidence. The authors concluded that the possibility that family presence may be detrimental to the psychological state of the patient, may slow down patient rounding or decrease the quality of patient education were unsubstantiated. In addition, a significant increase in risks of confidentiality breaches was not observed when open visiting policies were implemented. In fact, it appears that the benefits associated with communicating patient information during rounds exceed that risk. According to these authors, one of the only legitimate concerns pertains to the risk that family members experience increased anxiety when participating in patient rounds, but the authors note that this risk exists especially if the rounds are not organized in such a way as to take into account the presence of families at the patient's bedside. ${ }^{[13]}$

\subsubsection{Concerns regarding child visitors in ICUs}

Managing children visits in the intensive care environment may prove to be a source of stress and uncertainty for staff who work in these units, as well as for adult relatives who wonder if these visits are appropriate, if they lead to trauma in the children, or if there is a way to prepare children to visit a loved one in intensive care. Policies regarding children visits appear to vary considerably internationally. Hanley and Piazza ${ }^{[14]}$ concluded that when they were well prepared and supervised by an adult, these visits can have a positive impact in helping children manage and understand a stressful life event. However, they also insisted on the fact that nurses should be supported and trained to help them manage children visitors.

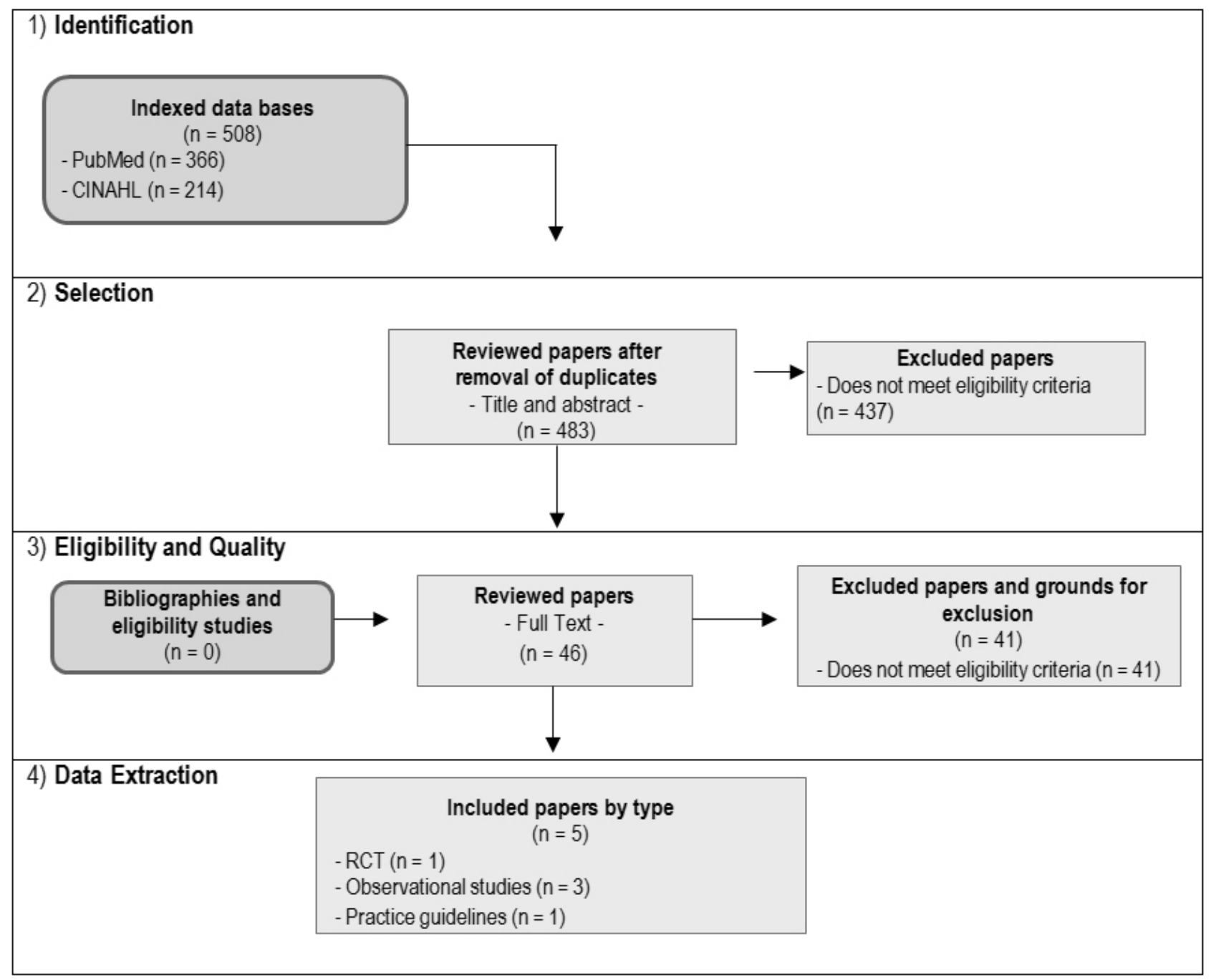

Figure 2. Document-selection diagram for the literature search on the risks of infection related to visiting policies 
3.2 Additional search for studies on risk of hospitalacquired infections and complications

The research strategy identified 483 papers. After going through all the steps to select and assess the eligibility of these documents, five papers were retained: a randomised control trial, ${ }^{[19]}$ three observational studies ${ }^{[20-22]}$ and a longitudinal study. ${ }^{[23]}$ The document selection diagram is presented in Figure 2. A summary description of the studies and their results are presented in Table 4.

Table 4. Practice guidelines and position statements

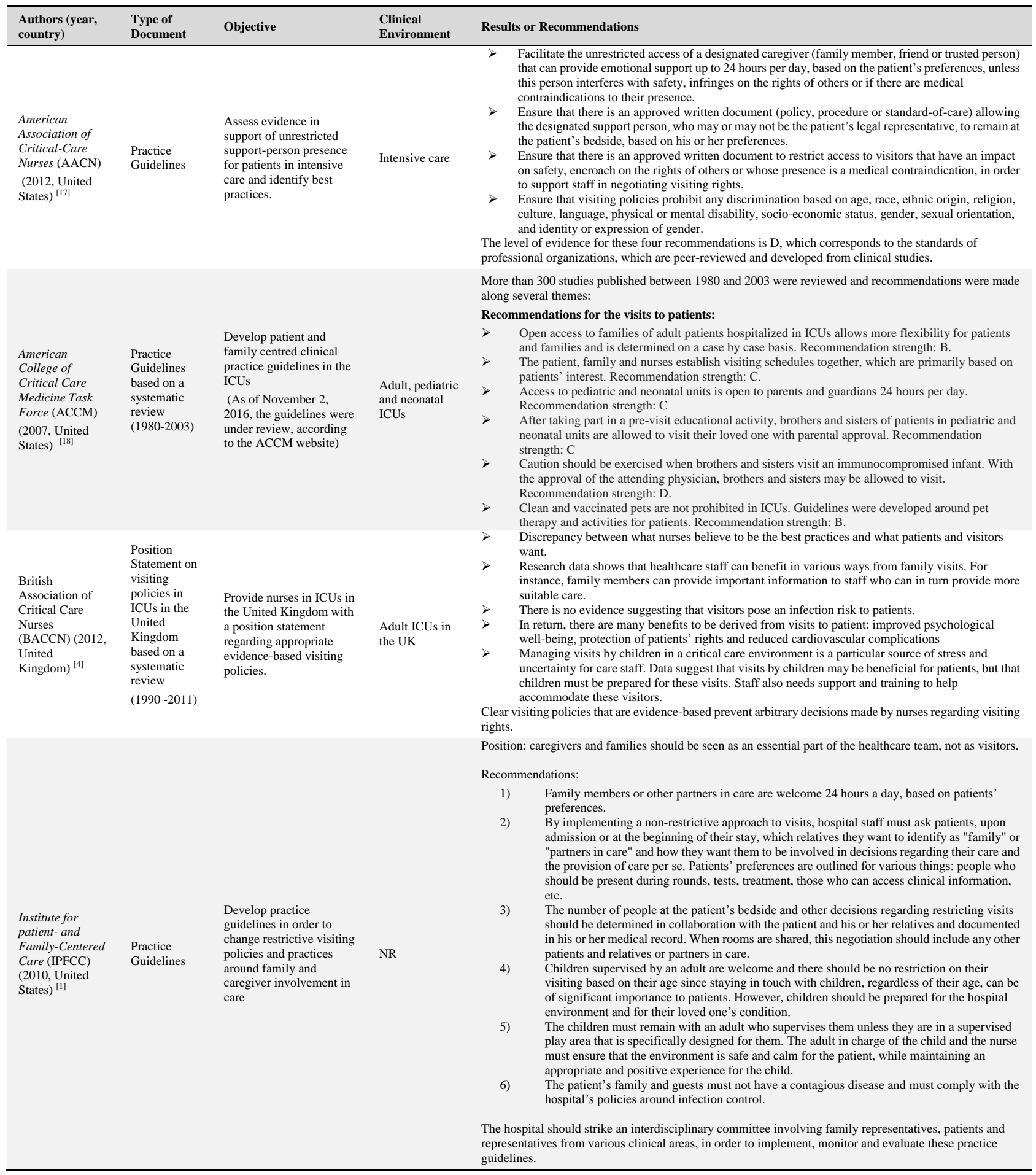


3.3 Practice guidelines and position statements pertaining to visiting policies

To develop its recommendations, the ACCM reviewed more than 300 studies published between 1980 and 2003. ${ }^{[18]}$ Results of the studies supported the continued presence of family members at the patient's bedside in ICUs, but also showed the importance of determining optimal visiting schedules based on the patient's preferences, in collaboration with nursing staff and family. They also underscored that parents or guardians of children hospitalized in pediatric or neonatal ICUs should have access to their child 24 hours per day, seven days a week. The AACN also recommends access without restriction to a designated caregiver when a patient is hospitalized in intensive care. According to this organization, the designated caregiver should be able to remain at the patient's bedside without any restriction, unless that person interferes with safety, impairs the rights of others, or if there is a medical counter-indication to their presence. ${ }^{[17]} \mathrm{AACN}$ guidelines also suggest that a written document attesting that the designated caregivers are allowed to remain at the patient's bedside should be prepared. In the BACCN's practice guidelines, presence of the family is cited as a potential way to respect patients' values and meet their needs as well as a way to protect their rights. These aspects, along with the absence of conclusive evidence regarding the potential risks posed by increased visitor presence, can constitute strong arguments to support flexible visiting schedules. ${ }^{[4]}$ These authors also stress that visiting policies should be clearer and more easily accessible for visitors. Both the ACCM and the BACCN recommend that children of all ages be allowed to visit with their hospitalized loved ones in adult, pediatric, or neonatal intensive care, subject to parental approval. ${ }^{[4,18]}$ To this effect, they also suggest that the staff receives training to facilitate visits by children, which represents a particular source of stress. ${ }^{[4]}$ They also recommend that caution be exercised with regard to brothers and sisters who wish to visit immunocompromised infants and that their visit be permitted only under physician approval. ${ }^{[18]}$ Finally, the IPFCC produced recommendations to support stronger presence and involvement of families in care teams in all hospital departments. Their main recommendations are in line with those of the ACCM, AACN and BACCN. ${ }^{[1]}$ See Table 3 for further descriptions of these organisations' guidelines and recommendations.

\subsection{Quality of the data}

According to our assessment, the methodological quality of three of the seven reviews presented here ${ }^{[8,12,16]}$ was good, while that of the other four ${ }^{[1,13-15]}$ was average to poor. This was primarily due to the lack of information on the literature search methodology, the absence of information provided either on inclusion criteria or quality of the included studies. The same goes for the quality of the practice guidelines, which we assessed as average because of methodological limitations associated with the lack of information on the databases used, selection methods, data eligibility assessment and data extraction. Therefore, it is difficult to determine the quality of the evidence and whether the recommendations contained in these practice guidelines are based on all available evidence. Another limitation associated with the evidence we reviewed pertains to the lack of measurement standards for some indicators or lack of description of how some concepts were measured (e.g., satisfaction, ease of communication). Although standardized, validated tools to measure anxiety, depression and emotional well-being or distress do exist, authors of the primary studies did not always indicate what tools were used to assess these variables. It is therefore impossible to know if the data are comparable from one study to another. For the same reasons, it is difficult to determine whether the benefits observed and reported in the studies are comparable across studies. In addition, it is very difficult to determine if the positive effects associated with open or flexible visiting hours are influenced by confounding factors, such as change in the staff's behaviors or attitudes, for example, and it did not appear as though these variables were controlled for. In fact, these factors are only rarely mentioned as having possibly influenced the studies' outcomes. Furthermore, the absence of a control group constitutes a weak point in most of the studies. Finally, since the studies were predominantly conducted in intensive care environments, results cannot be extrapolated to all types of care units. Given these limitations, the extent to which, or how, open or flexible visiting policies impact patients, families and staff remains somewhat unclear. Nevertheless, in spite of these methodological limitations, available evidences suggest that open or flexible visiting policies are beneficial for patients, given some restrictions, and certainly preferred over restrictive policies.

The quality of the data from the primary studies documenting the risks of infection associated with the expansion of visiting hours was also hindered by a few factors. Methodological designs were often pre-post, without any control for potentially confounding factors, such as change in the attitude of medical or nursing staff or the addition of resources for the prevention of infections, for instance.

\section{DisCuSSION}

Given the current trend towards promoting and adopting patient and family-centred care models, several renowned national and international health organizations recommend the implementation of less restrictive visiting policies and 
practices that promote the presence and engagement of family members as partners in care. These organizations agree on the fact that it is necessary to move away from the perception that close family members are mere visitors and, instead, to consider them as partners that can promote the quality and safety of care. ${ }^{[1,24]}$ Arguments underlying this culture shift are based in large part on data showing greater patient and family satisfaction with more flexible visiting policies, decreased levels of psychological distress for both patients and families, a greater feeling of emotional support and better communication with healthcare teams. ${ }^{[4,8,15,17]}$ Although the data from these studies have some methodological limitations, the fact that the majority of the studies point in the same direction bolsters the argument.

Another argument supporting the adoption of flexible policies is based on the observation that flexible visiting hours in ICUs are not associated with increased hospital-acquired infection rates ${ }^{[20]}$ or septic complications. ${ }^{[19]}$ Limiting visits would therefore not be an appropriate measure to reduce infection rates. ${ }^{[20]}$ Some authors suggest that the emphasis should instead be placed on the promotion and strengthening of hygiene and infection prevention measures. ${ }^{[8,17,18]}$ However, these studies also have methodological limitations. With the exception of one RCT, the identified studies were mainly uncontrolled pre-post studies. Amongst other things, infection rates could have been influenced by the effect of other factors, which were not controlled for in these studies. Consequently, further well controlled-studies should be conducted in order to clarify this.

Authors of the studies we reviewed agree on the importance of encouraging care units to show openness towards family presence, particularly in intensive care and in the case of vulnerable clienteles such as children, frail elderly, and people with critical, advanced, or end-of-life illnesses. Policies that foster the presence and involvement of families may also facilitate transitions, such as preparing for discharge and returning home, which generally happen in the presence of families. However, entirely unrestricted access to patients, with no limitations whatsoever may not be desirable for all patients, families and staff, specifically to avoid interfering with care and to promote rest and recovery. Changes to visiting policies should take the type of care unit, the context and clientele into account. Policies should also uphold the patient's right to decide whether he or she wants visits and to what extent, including the presence of their caregivers. Some authors also stressed that it was important for patients to have more control over the terms of visits, particularly for patients who have a serious illness, advanced stage disease or in end-of-life care. ${ }^{[3,25,26]}$ Above all, visiting policies should consider the needs and preferences of patients but this should be balanced against the security and well-being of all patients. This was also clear in the guidelines we reviewed.

Adopting flexible visiting policies represents a significant challenge. This cannot be implemented without the involvement and commitment of all stakeholders. The opinions and preferences of staff regarding open and flexible visiting policies are often mixed. Regardless, the available data suggests that increased presence of caregivers at the patient's bedside leads to greater satisfaction and to improved staff engagement once the change has taken effect in the care environment. ${ }^{[11,12]}$ A rigorous review process, including all stakeholders (management, care teams, patients and families) should be carried out to ensure that visiting policies balance all the issues and key perceptions in the transition towards more flexible policies that foster family caregiver engagement. ${ }^{[1,17]}$ As a first step, patient surveys could help identify the needs and preferences of patients, caregivers and family members in different care contexts, and information on staff's point of views could be collected in order to identify barriers and facilitators associated with policy change, and pinpoint potential upstream solutions. A feasibility study in units that are ready to undertake a pilot project could also be an interesting step towards using lived experiences to refine the policy and its application. ${ }^{[27]}$

Healthcare centers should also make sure policies and rules are consistent between their hospitals and that the information is easily accessible to patients and families, either on the organizations' websites or in the documentation given to patients. When policies are not uniform across hospitals within the organisation, some unit leaders will encourage the presence of families and provide them with flexible access to their loved ones whilst others will not. These decisions, while laudable since they follow recommendations made by professional associations, may lead to inequities for some patients and families and eventually confusion with regard to what is allowed, tolerated or not permitted. This does not encourage true "openness" towards the presence of families on an organization-wide basis.

The present review is not without its limitations and conclusions need to be interpreted with some caution. Papers we reviewed were not all of good quality and contained sometimes significant methodological limitations. Amongst other things, all primary quantitative studies included in the synthesis studies and reviewed in the practice guidelines used an uncontrolled pre-post methodological design. This type of design limits the strength of the evidence from the outset. In addition, there was substantial variability between studies either in the way satisfaction was assessed, in defining impact or result indicators, or in the choice of measurement tools. 
Some papers reviewed here were published by organizations that promote patient and family-centred care as well as family engagement in hospital environments. A differential information bias, which overestimates real benefits associated with open or flexible visiting policies, could therefore have found its way in the issued recommendations. Promoting a model of care involves an initial belief in its merits. In itself, this is not problematic if the advantages and disadvantages are analyzed in a systematic manner and presented in a transparent fashion to maximize the implementation of change based on solid, unbiased, empirical evidence. Finally, a large part of the available evidence is based on the identification of perceptions, opinions and beliefs, and this information must be interpreted within this context. Although it is tempting to extrapolate, this should be done with caution. For example, information from a survey where nurses or family members are asked their opinion concerning the advantages and dis- advantages of increased presence of caregivers and visitors at the patient's bedside and the demonstration, through objective measures, of the effect of increased presence on a patient's heartrate, or on the productivity of healthcare staff is not the same. Nonetheless, when issues pertain to satisfaction or preferences, there is no objective way to measure these inherently subjective constructs. Studies in which result indicators are based on objective measures (physiological markers, length of stay, mortality rates) or on validated subjective measures, as well as studies that use proven methodologies to control for confounding factors remain necessary in order to better understand the impacts and issues surrounding continued family presence at the bedside and visiting policies.

\section{CONFlicts of InTERest Disclosure}

The authors declare they have no conflicts of interest.

\section{REFERENCES}

[1] Institute for patient-and family-centered care. Changing hospital "visiting" policies and practices: supporting family presence and participation. Institute for Patient- and Family-Centered Care (IPFCC); 2010.

[2] Ismail S, Mulley G. Visiting times. BMJ. 2007; 335(7633): 1316-7. PMid: 18156246. https://doi.org/10.1136/bmj.39420.39 2373. BE

[3] Medves JM, Harrison MB, Tranmer JE, et al. Visiting policies in hospitals: a systematic review of their effect on pediatric and adult populations and their visitors. The Nursing Journal. 2009; 01: 23-32.

[4] Gibson V, Plowright C, Collins T, et al. Position statement on visiting in adult critical care units in the UK. Nursing in Critical Care. 2012; 17(4): 213-8. PMid: 22698164. https://doi.org/10.1111/j. 1478-5153.2012.00513.x

[5] Lee MD, Friedenberg AS, Mukpo DH, et al. Visiting hours in New England intensive care units: stragtegies for improvement. Critical Care Medicine. 2007; 35(2): 497-501. PMid: 17205012. https://doi.org/10.1097/01.CCM.0000254338.87182.AC

[6] Spuhler VJ. Review of the literature on visiting hours in the intensive care unit. 2007.

[7] Berwick D, Kotagal M. Restricitng visiting hours in ICUs: Time to change. Journal of the American Medical Association. 2004; 29(6): 736-7. PMid: 15304472. https://doi.org/10.1001/jama. 292 .6 .736

[8] Smith L, Medves JM, Harrison MB, et al. The impact of hospital visiting hour policies on pediatric and adult patients and their visitors. Joanna Briggs Institute Library of Systematic Reviews. 2009; 7(2): 38-79. https://doi .org/10.11124/01938924-2009070 20-00001

[9] Kung J, Chiappelli F, Cajulis O, et al. From systematic reviews to clinical recommendations for evidence-based health care: validation of revised assessment of multiple systematic reviews (R-AMSTAR) for grading of clinical relevance. The Open Dentistry Journal. 2010; 4(1). PMid: 21088686. https://doi.org/10.2174/18742106 01004010084

Published by Sciedu Press
[10] Brouwers MC, Kho ME, Browman GP, et al. AGREE II: advancing guideline development, reporting and evaluation in health care. Canadian Medical Association Journal. 2010; 182(18): E839-E42. PMid: 20603348. https://doi.org/10.1503/cmaj.090449

[11] Cappellini E, Bambi S, Lucchini A, et al. Open intensive care units: a global challenge for patients, relatives, and critical care teams. Dimens Crit Care Nurs. 2014; 33(4): 181-193. PMid: 24895947. https://doi.org/10.1097/DCC.0000000000000052

[12] Ciufo D, Hader R, Holly C. A comprehensive systematic review of visitation models in adult critical care units within the context of patient- and family-centred care. International Journal of Evidence-Based Healthcare. 2011; 9(4): 362-87. PMid: 22093387. https://doi.org/10.1111/j.1744-1609.2011.00229.x

[13] Davidson JE, Savidan KA, Barker N, et al. Using Evidence to Overcome Obstacles to Family Presence. Critical care nursing quarterly. 2014; 37(4): 407-21. PMid: 25185768. https://doi.org/10.1 097/CNQ. 0000000000000041

[14] Hanley JB, Piazza J. A visit to the intensive cares unit: a familycentered culture change to facilitate pediatric visitation in an adult intensive care unit. Critical Care Nursing Quarterly. 2012; 35(1): 113-22. PMid: 22157497. https://doi.org/10.1097/CNQ.0b $013 \mathrm{e} 31823 \mathrm{~b} 1 \mathrm{ecd}$

[15] Whitton S, Pittiglio LI. Critical care open visiting hours. Critical Care Nursing Quarterly. 2011; 34(4): 361-6. PMid: 21921719. https://doi.org/10.1097/CNQ.0b013e31822c9ab1

[16] Kynoch K, Chang A, Coyer F, et al. The effectiveness of interventions to meet family needs of critically ill patients in an adult intensive care unit: a systematic review update. JBI Database of Systematic Reviews and Implementation Reports. 2016; 14(3): 181-234. PMid: 27532144. https : //doi.org/10.11124/JBISRIR-2016-2477

[17] American Association of Critical-Care Nurses. Family presence: visitation in the adult ICU. Critical Care Nurse. 2012; 32(4): 76-8.

[18] Davidson JE, Powers K, Hedayat KM, et al. Clinical practice guidelines for support of the family in the patient-centered intensive care unit: American College of Critical Care Medicine Task Force 2004- 
2005. Critical Care Medicine. 2007; 35(2): 605-22. PMid: 17205007. https://doi.org/10.1097/01.CCM.0000254067.14607.EB

[19] Fumagalli S, Boncinelli L, Lo Nostro A, et al. Reduced cardiocirculatory complications with unrestrictive visiting policy in an intensive care unit: results from a pilot, randomized trial. Circulation. 2006; 113(7): 946-52. PMid: 16490836. https://doi.org/10.1161/ CIRCULATIONAHA . 105. 572537

[20] Adams S, Herrera A, Miller L, et al. Visitation in the intensive care unit: impact on infection prevention and control. Critical Care Nursing Quarterly. 2011; 34(1): 3-10. PMid: 21160294. https: //doi.org/10.1097/CNQ.0b013e31820480ef

[21] Malacarne P, Corini M, Petri D. Health care-associated infections and visiting policy in an intensive care unit. American Journal of Infection Control. 2011; 39(10): 898-900. PMid: 21783279. https://doi.org/10.1016/j.ajic.2011.02.018

[22] Peluso AM, Harnish BA, Miller NS, et al. Effect of young sibling visitation on respiratory syncytial virus activity in a NICU. Journal of Perinatology. 2015; 35(8): 627-30. PMid: 25836315. https://doi.org/10.1038/jp.2015.27
[23] Tang CS, Chung FF, Lin MC, et al. Impact of patient visiting activities on indoor climate in a medical intensive care unit: a 1-year longitudinal study. American Journal of Infection Control. 2009; 37(3): 183-8. PMid: 19178985. https://doi.org/10.1016/j. ajic. 2008.06.011

[24] Canadian Foundation for healthcare improvement. Much more than just a visit: a review of visiting policies in select Canadian Acute Care Hospitals. 2015.

[25] Gardner G, Collins C, Osborne S, et al. Creating a therapeutic environment: a non-randomised controlled trial of a quiet time intervention for patients in acute care. International Journal of Nursing Studies. 2009; 46(6): 778-86. PMid: 19167711. https: //doi.org/10.1016/j.ijnurstu.2008.12.009

[26] Gray H, Adam J, Brown D, et al. Visiting all hours: a focus group study on staff's views of open visiting in a hospice. International Journal of Palliative Nursing. 2011; 17(11): 552-60. PMid: 22240633. https://doi.org/10.12968/ijpn.2011.17.11.552

[27] Frampton S, Guastello S, Brady C, et al. Patient-centered care improvement guide. Derby, CT: Planetree; 2008. 